\title{
СТРУКТУРНИЙ АНАЛІЗ ПОНЯТТЯ “ЯКІСТЬ ЖИТТЯ” КРІЗЬ ПРИЗМУ ЯКОСТI ОСВІТИ
}

\section{Horbachevsky Ternopil State Medical University \\ STRUCTURAL ANALYSIS OF LIFE QUALITY THROUGH THE LENS OF EDUCATION QUALITY}

\begin{abstract}
Мета роботи - виявлення спільних аспектів у визначенні якості життя у різних наукових галузях для виокремлення педагогічних детермінантів вказаного поняття.

Основна частина. Якість життя як складна і багатогранна категорія є предметом дослідження багатьох наукових дисциплін. Сама концепція якості життя та спроби її кількісно розрізняти залежать від методів дослідження та інструментів вимірювання, придатних для даної дисципліни. Категорія якості життя має практичний характер, оскільки вона є цікавою в індивідуальному масштабі - кожній людині, а також у колективному - місцева, регіональна якість тощо. Теоретичний аналіз поняття “якість життя” дав можливість виокремити спільні та відмінні характеристики у різних галузях його вивчення. Окрім цього, на основі структурного аналізу, вдалося визначити конкретні детермінанти якості життя щодо педагогіки.

Висновки. Якість життя у педагогіці сприймається в контексті розвитку особистості людини, тому її можна визначити як “почуття задоволення життям”, яке можливе за умови багатовимірного розвитку та самозростання людини і реалізації ії прагнень та життєвих цілей. Вона прямо пропорційно залежить від рівня якості освіти і навчання.
\end{abstract}

Ключові слова: якість життя; якість; щастя; освіта; задоволення життям.

The aim of the work - identification of common aspects in determining the quality of life in different scientific fields that help to distinguish pedagogical determinants of this concept.

The main body. Quality of life as a complex and multifaceted category and it is the research subject of many scientific disciplines. The concept of quality of life and attempts to quantitatively differentiate depend on research methods and measuring instruments suitable for the discipline. The category of life quality is practical because it is interesting on an individual scale - for every person, as well as in the collective - local, regional quality, etc. The theoretical analysis of the concept of "life quality" gave us a possibility to distinguish common and distinctive characteristics in various fields of its study. In addition, it was possible to identify specific determinants of quality of life in relation to pedagogy on the basis of structural analysis.

Conclusions. The quality of life is perceived in the context of the person's development, so it can be defined as a "sense of life", which is possible to identify as a multidimensional development and self-development of human and the realization of his aspirations and life goals in pedagogy. Therefore, it is directly proportional to the quality of education and training.

Key words: life quality; quality; happiness; education; life satisfaction.

Вступ. У більшості країн світу помітним є збільшення значення і зацікавлення школою як навчальною інституцією. Це проявляється у діяльності, спрямованій на вдосконалення вітчизняної освіти та створення такої моделі навчання, яка забезпечить учням можливість застосовувати власні вміння і навички у реальному житті й одночасно стане гарантією розвитку цивілізації. В освітній політиці високорозвинених кран світу така гарантія підтверджується високою якістю освітніх послуг та

(C) М. Я. Кічула ефективною роботою школи (наприклад, результат програми PISA). Все це, у свою чергу, ставить високі вимоги перед педагогічним колективом навчальних закладів, які повинні бути добре інформовані і розуміти першорядність якості освіти й забезпечення такої якості. А, відповідно до цього, вищі навчальні заклади, що готують педагогічні кадри, мусіли б першочергово базуватися на стратегіях забезпечення якості освіти.

До світових авторів, котрі визначили якість як центр своїх наукових досліджень, належать: 
R. A. Cummins, B. Lindstrom, R. L. Schalock, R. Renwick, I. Brown, A. Campbell, E. Convers, D. J. Schneider, F. Andrews, S. B. Withley, W. I. Rodgers, J. Goodal, D. T. Hall, D. Felce, J. Perry, E. Allardt, H. Schipper, J. Clinch, V. Powell, J. M. Reaburn, I. Rootman, M. Bach, M. H. Rioux.

Серед польських науковців це: J. Czapiński, R. Derbis, A. Bańka, S. Kowalik, M. Oleś, K. de WaldenGałuszko, R. Kolman, A. Zalewska, L. Wołowicka, H. Sęk, B. Weinert, S. Sadowska та інші.

Проблему пошуків взаємозв'язку між освітою і якістю життя населення висвітлювали у своїх працях українські дослідники: В. Васильєва, О. Величко, Л. Гриневич, Л. Даниленко, М. Дарманський, С. Квіт, Л. Колесников, В. Кремень, В. Луговий, Т. Лукіна, Г. Мартинов, С. Ніколаєнко та ін.

Мета роботи - виявлення спільних аспектів у визначенні якості життя у різних наукових галузях для виокремлення педагогічних детермінантів вказаного поняття.

Основна частина. Якість життя - динамічна категорія, що змінюється і в часі, і в просторі - в даний час $€$ надзвичайно популярною серед представників гуманітарних та соціальних наук і надзвичайно відкритим терміном, що розглядається 3 різних точок зору. Як правило, це міждисциплінарне поняття означає почуття сатисфакції людини (або соціальної групи), що виникає внаслідок задоволення ряду потреб, і його значення має показати сенс або оцінити життєвий досвід індивідуума [1]. Оцінювати якість життя, як зазначалося, можливо 3 урахуванням багатьох рівнів, конкретних моментів або, $з$ точки зору усього життя, на кожному етапі розвитку. Однією із визначальних сфер впливу на якість життя людини є освіта. Можливості дидактичного та педагогічного впливу на людину знижуються із дорослішанням учнів. Тому, мабуть, надзвичайно важливим $€$ пошук педагогічних рішень у сфері оптимізації якості розвитку та життя дітей. Від якості здійснення дидактичної та виховної функції дорослих (батьків, вихователів, учителів) щодо дітей може залежати розвиток і якість їхнього майбутнього життя. Переконливі факти наводять на висновок про те, що якість $є$ природно педагогічною категорією, а якість життя $є$ метою і одночасно результатом навчальних взаємодій.

Дуже часто термін “якість” використовується у різноманітних ситуаціях для визначення об’єктів та серій явищ, що виникають у повсякденному житті. Щоразу, як тільки концепція використовується у сенсі сукупності об'єктивних ознак, що окрес- люють певні особливості й дозволяють відрізнити певний об'єкт чи явище від інших, відповідно, i передбачає наявність зразка стандарту, який формулює певні вимоги до цих ознак предмета, ефекту, явища або напряму дій. У такому сенсі якість - це сума характеристик продукту, зокрема самого виробу або дій його виконання і найчастіше оцінювана як гарна якість - погана якість. Оцінка базується на існуванні об'єктивного чи ідеального речового зразка або ж прикладу виконання. В іншому випадку, тобто закономірності дії, якість сприймають як ефективність у синтетичному сенсі [2].

Усі предмети, явища, дії містять дві характеристики: не лише якісну, але й кількісну. Остання - це розмір, ступінь інтенсивності певної якості. Завдяки комбінованому сприйняттю двох характеристик можна встановити сутність, специфічність певного предмета, явища чи дії. У прямому сенсі, якість прямо відноситься до суб'єкта - людини, що дозволяє їй брати виражену участь у формуванні особистості [3]. Якість буває випадкова та цільова (призначена), позитивна й нейтральна, окрім цього, вона може бути множинна або одинична. Всі вони мають відношення до певного успіху чи успіхів, що, у свою чергу, може легко або ж, навпаки, важко досягатися.

Вищезгадане тлумачення якості (у сенсі її множинності та напрямів) вказує на те, що воно викликає позитивний досвід у людей, але й містить у собі певні стани, що не завжди можливо передбачати або немає бажання їх визнавати або переживати (наприклад, страждання, смерть). Однак вони не позбавлені якості, оскільки глибоко вкорінені в людському існуванні як щастя, задоволення та радість життя. Питання про роль якості в житті людини автоматично піднімає проблему його значення, аспектів, детермінантів, врегулювань і т. д. Якість, по відношенню до життя дитини, ототожнюється з рівнем задоволення ії потреб дорослими та якістю умов, у яких відбувається особистий розвиток. Таке значення дозволяє індивіду функціонувати на вищих рівнях, у сфері набуття нових навичок, “збагачення себе”. Польський науковець Р. Колман вважає, що якість життя поширюється на все, 3 чим люди живуть щодня. Автор вважає, що якість життя є найважливішим із відомих видів якості [4].

Генеза поняття “якість життя” бере початок у другій половині XX століття, хоча проблеми, пов’язані з нею, були відомі людям із самого початку світу. Насамперед, у філософії підносилося питання про “хороше життя”, а щоб описати його, використо- 
вували термін “щастя”. Шукаючи початок поняття “щастя”, натрапляємо на перший пов’ язаний термін: “сприятлива доля” - “процвітання”, які виступали у греків найчастіше під назвою “добра”, а в релігійних і міфологічних термінах - “евдаймонія”. До поняття “везіння” наближалися його певні варіанти - більш точні поняття - передусім “чарра” - це стан насолоди, що характеризується довговічністю, та “евфросиня”, що означає веселу, щасливу вдачу, як чинник позитивного життя і “ольбос” - чоловік, який процвітає у повноті життя та радості. Почуття “блаженства” - поняття, найближче до щастя, означало задоволення, яке можливо лише для богів і душ в Елізіумі [5]. Філософські відповіді на питання про щасливе життя, як правило, були універсальними та постулатами, їх часто трактували як готові пропозиції - “ознака життєвого напрямку” для людей, що жили в різний час та культурах. Вони могли протистояти своїм власним життєвим принципам, що пропонувалися філософією чи релігією, а потім прояснити свій спосіб життя. Стародавні, але також і сучасні філософи не змогли створити однозначну концепцію щастя [6].

Поява терміна “якість життя” тісно пов’язана 3 виникненням найвищого економічного зростання в Сполучених Штатах у 1960-х роках. У той же час зросла соціальна патологія, і в цих умовах було поставлено перше питання про майбутні наслідки промислового розвитку для суспільства. Спочатку термін “якість життя” включав у себе все, що стосувалося впливу науково-технічної революції на людське життя, тобто товари, які необхідно доставити споживачеві в розвиненому “промисловому” суспільстві для його благополуччя. У цьому сенсі термін “добробут” використовувався для визначення якості життя. Проте з часом було встановлено, що зростання економічних досягнень не зробило суспільство більш задоволеним життям [7].

Виходячи з вищезгаданих аспектів (у рамках тенденції охорони навколишнього середовища, урбанізації, заснованих на соціально-психологічних мотивах), було створено концепцію якості життя, яка, враховуючи повний спектр не лише “суто” економічних, а й екологічних (соціальних) потреб, $є$ вираженням, самореалізацією та прийняттям, соціальним визнанням, зв'язком з іншими людьми, що $€$ альтернативою наслідкам промислового та технологічного розвитку. Існуюча (матеріальна) організація життя була відхилена, необхідною умовою стало те, що варто знайти нові цінності життя і надати йому нові якість і значення [8].
Поняття “якість життя” є проблемою не лише філософії, але й багатьох галузей науки, навіть соціальної політики. Серед можливих способів концептуалізації категорії “якість життя" можна виокремити основні напрями досліджень та дискусій, пов’язаних із ї̈ сприйняттям в об’єктивному сенсі (що відбуваються в основному в соціології та економіці) та суб'єктивному (характерному для психологічного підходу) [9]. Шляхи включення категорії “якість життя” можуть бути додаткові (окрім згаданих), розділені на широкі та вузькі.

Цілісне сприйняття людини та її життя особливо популярне в гуманітарних науках, посилило інтерпретацію якості життя суб'єктивною сферою. Отже, нематеріальні активи були включені до їі сфери: здоров’я, свобода, освіта тощо. Якість життя сприймається тут у вузькому значенні щодо індивідуальних потреб людей у вимірах життя, бажано на основі об’єктивних умов, що існують у даній країні [10].

Площин, на яких якість життя має наукову основу, $є$ достатньо у сучасній науці. Використання інструментів та методів вимірювання, специфічних для даної категорії, веде до появи безлічі дискусійних напрямів та досліджень, і вони в основному грунтуються на психології, соціології, економіці та медицині, а також на педагогіці. Обговорюване питання особливо близьке до психології, незважаючи на те, що воно є відносно новим (у класичній психології термін “якість життя” не використовувався безпосередньо), адаптація до цієї науки призвела до появи спірних питань, бо якість є особливістю - і тому властивість предмета, речі, суб’єкта, процесу - це відношення функцій, наприклад, добрий, корисний. Інша відмінність стосується різниці між якістю у вищезазначеному описовому сенсі та якістю в нормативному значенні. Ще інша (у зв'язку з відсутністю чіткості) передбачає використання терміна “якість” відносно людини, її особистості. Людина є якістю сама по собі, і в психології ця аксіома ніколи не була підірвана. Термін “якість життя” в цій дисципліні запозичений із метою практики, тому він, за своєю природою, не є суто психологічним [11]. У даний час зростання інтересу до проблеми якості життя у психології сприяв появі основної гуманістичної психології під назвою “позитивна психологія”. Ї̈̈ творцем і пропагандистом вважається Мартін Селігман, професор психології Університету Пенсильванії. Автор обрав концепцію протидії негативній психології (на противагу медичної та клінічної моделі), яка панувала в минулому сто- 
літті [12], як основу для створення цієї тенденції. Саме так рух почав розвивати ідею гарного життя та сильних сторін людини [13]. У своїх припущеннях ця галузь досі визнає та доповнює досягнення “традиційної” психології, не оцінюючи їх негативно. Ї̈̈ метою є збагатити людський образ і систематизувати поглиблене вивчення того, що становить основу людського буття. Ця нова галузь психології пропонує працювати над розвитком людського потенціалу для покращення власного життя [3]. У психології якість життя означає широко зрозуміле відчуття задоволення (благополуччя) і щастя людини. У цьому підході людина постає як цілком інтегрована всередину з певними життєвими ситуаціями, не лише взаємодіючи із світом, але і в системі проектів і життєвих перспектив [14].

У соціологічному підході - 3 урахуванням характеру показників та рівня їх аналізу - мова йде про якість життя, перш за все, в об'єктивному та суб'єктивному сенсі (з урахуванням іiі взаємин 3 аксіологічною системою, будучи передумовою посилання на соціальну політику або систему цінностей певної одиниці) та якості життя в широкій і вузькій перспективі. Така якість життя складається 3: об'єктивних умов (економічної ситуації, житлових умов, природного середовища та ін.) та суб'єктивних (наприклад, добробут, оцінка загальних та особливих умов життя, зафіксованих у плані задоволення, щастя, тривоги тощо) [15]. Переважна більшість авторів оцінює об'єктивні та суб'єктивні складові, відрізняючи в кожному з них фізичні, соціальні, психологічні та міжособистісні аспекти. Якість життя інтерпретована крізь призму таких показників, як: соціальні норми, система цінностей та принципів суспільного життя. Прагнення пояснити значення та залежність якості життєвих факторів привело до розробки досліджень у цій галузі, також на рівні економіки та статистики.

Таким чином, дослідження та навчання об'єктивної оцінки якості життя в економічному плані мають багату традицію та пов'язані з розробкою методологій для вимірювання економічного добробуту (рівня матеріальних умов життя), розширені деякими соціальними або екологічними аспектами (показниками) [4]. На рівні економіки якість життя сприймається в контексті її вимірюваних особливих показників, беручи до уваги так званий кошик товарів і послуг, мінімум соціального та споживчого попиту, обсяг основних потреб або соціальних вигод. У запитах про об'єктивність вимірювання якості життя також переважають статистичні опи- тування. На цьому рівні якість життя ототожнюється з так званими соціально-економічними умовами життя, i, перш за все, рівнем задоволення життєвих потреб. Даний підхід багато в чому відповідає визначенню експертної комісії ООН, згідно з якою поняття “якість життя” включає “загальні реальні умови життя людей та рівень їх матеріальних та культурних потреб” [9]. Ця категорія включає в себе такі особливості, як: умови праці, рівні заробітної плати, споживання, володіння довгостроковими споживчими товарами, житлове становище, стан здоров'я та соціальної допомоги, освіти та культури тощо [13]. Галузь, для якої пріоритетним $є$ якість життя людини, - це медицина. Спроби оперативної стандартизації концепції “якості життя” почалися в медицині та психології здоров’ я. Визначення поняття “здоров'я” було поштовхом до теоретичних міркувань Всесвітньої організації охорони здоров’я - ВООЗ, що вийшли за рамки традиційного медико-біологічного підходу, і включили негативні медичні поняття, такі, як: захворюваність, смертність [3]. Навіть це перше “позитивне” визначення здоров’я, мабуть, революційне, оскільки воно враховує три виміри: фізичний, психологічний та соціальний добробут, який у даний час репресований і його важко реалізувати [16]. Відповідно до концепції здоров’я ВООЗ, відхиливши ії біомедичну модель, здоров'я означало не тільки відсутність хвороби чи інвалідності, але й гарний фізичний, психічний та соціальний стан [17]. У сучасних концепціях здоров'я цілісне, динамічне, багатовимірне та багаторівневе й системно зрозуміле, включаючи фізичний, психологічний, соціальний та духовний рівні, це означає процес самозростання у взаємодії з вимогами навколишнього середовища [16]. Низка зарубіжних вчених вважає, що здоров'я - це процес, який виникає внаслідок взаємного впливу існуючих людських ресурсів, поведінки та щоденних потреб життя. Це означає використання біологічних, психологічних і соціальних потенціалів для задоволення зовнішніх та внутрішніх потреб і досягнення індивідуальних та соціальних цілей без хронічного порушення динамічної рівноваги [18]. Якість життя розглядається в медицині на основі вищевикладеного тлумачення цілісного сприйнятого об'єктивного здоров'я [3, 19].

Скорочені поняття якості життя на рівні обраних наукових дисциплін доводять, що воно не $\epsilon$ однозначною категорією. Буває, що в межах однієї галузі автори розглядають його по-різному (табл. 1). Якість життя, як уже зазначалося, також 
Таблиця 1. Структурний аналіз поняття “якість освіти”

\begin{tabular}{|c|c|c|c|c|c|c|}
\hline \multirow[b]{2}{*}{ Дефініції } & \multicolumn{6}{|c|}{ Галузі вивчення } \\
\hline & 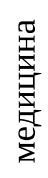 & 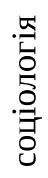 & 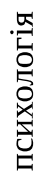 & 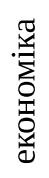 & 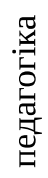 & 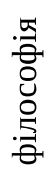 \\
\hline $\begin{array}{l}\text { Сприйняття людиною своєї позиції у житті, у тому числі фізичного, психічно- } \\
\text { го та соціального благополуччя, залежно від якості середовища, в якому вона } \\
\text { живе, а також ступеня задоволення конкретним рівнем життя та іншими скла- } \\
\text { довими психологічного комфорту }\end{array}$ & & & + & & + & + \\
\hline Суб’єктивне відчуття, близьке до щастя й особистого благополуччя & + & + & & & & + \\
\hline Сукупність параметрів, що віддзеркалюють вимірювання перебігу життя & & & & & & \\
\hline Взаємозв’язок між якістю життя і рівнем життя & + & + & & + & & \\
\hline Критерій оцінювання успіху у формуванні особистості через виховання, освіту & & & & & & \\
\hline Ступінь задоволення матеріальних, культурних і духовних потреб людини & + & + & + & + & + & \\
\hline $\begin{array}{l}\text { Повний спектр не лише “суто” економічних, а й екологічних (соціальних) по- } \\
\text { треб, є вираженням, самореалізацією та прийняттям, соціальним визнанням, } \\
\text { зв’язком з іншими людьми }\end{array}$ & & + & & + & + & + \\
\hline Широко зрозуміле відчуття задоволення (благополуччя) і щастя людини & + & & + & + & + & \\
\hline
\end{tabular}

не має точного визначення і у педагогіці. 3 огляду на мету цієї статті, яка полягає в тому, щоб зосередити увагу на обговорюваному питанні з точки зору педагогічної науки, доречним є виокремлення певних детермінантів даного поняття “якість життя” з педагогічної точки зору.

Питання якості життя вивчається, як зазначено вище, у багатьох галузях науки (зокрема психологіï), але в педагогіці обговорюване питання було предметом інтересу для теоретиків та практиків. Можна сказати, що це наука у створенні правильних (педагогічних) основ теорії якості життя, відмінних від предмета вивчення інших дисциплін. Якість життя $є$ міждисциплінарною науковою сферою, отже, її концептуалізація та оцінка, що веде свій власний курс у кожній галузі, не впливає на висновки в педагогіці [7]. Кожне послідовне поле врахування якості життя (використання досягнень інших галузей) може сприяти розвитку теорії та створенню інструментів дослідження для ії вимірювання і відкриває у педагогіці шлях до вивчення цієї проблеми.

Ряд чинників спричиняє потребу в педагогічному аналізі та вимірюванні якості життя, в тому числі: трансформації цивілізації - в першу чергу у вимірі схвалених системних цінностей, зміни способу життя, освітніх припущень, зміни методів та сфери досліджень людського життя [7]. В даний час важливу роль (особливо в гуманітарних науках) приписують вивченню суб’єктивного почуття якості життя. Центр тяжіння був зміщений у них 3 діагностики об’єктивних детермінант до результатів індивідуальних критеріїв оцінки, підкреслюючи важливість мотивації, системи цінностей, поглядів, інтересів, творчості та людської ефективності для формулювання своїх оцінок про життя. Ще одна польська дослідниця А. Віатровська доповнює цю концепцію і визначає якість життя в суб’ єктивному розумінні, тобто благополуччя та оцінки людей у власних фізичних, матеріальних та психосоціальних аспектах, а також в екзистенціальному вимірі, що включає світогляд, почуття життя і цінності. Цей вимір використовується для отримання відповідей на питання про задовільне і цінне існування [20]. У рамках цього підходу якість життя все більше позиціонується в таких детермінантах, як: можливості розвитку людини, використання їі особистого потенціалу або відповідність бажаного осмислення середовища [21]. Також підкреслюється, що якість не може бути обмежена лише фізичним виміром, оскільки лише з можливістю збагачення психічних та духовних сфер людської особистості цілком розкривається її сутність.

Висновки. Таким чином, якість природним шляхом вписується в інтереси педагогіки, яка зосереджує увагу на проблемах людини (якість їі розвитку та життя) і шукає оптимальні умови для формування та вдосконалення власного об’єкта - якості освіти. Інтерес педагогіки до якісного виміру людського життя доводить її гуманістичний характер. 


\section{Список літератури}

1. Baumann K. Jakość życia w okresie późnej dorosłościdyskurs teoretyczny / K. Baumann // Gerontologia Polska. No. 14 (4). - 2006. - S. 165-171.

2. Pszczołowski T. Mała encyklopedia prakseologii i teorii organizacji / T. Pszczołowski. - Wrocław, 1978. - 346 s.

3. Daszykowska J. Jakość życia w perspektywie pedagogicznej / J. Daszykowska. - Kraków : Oficyna Wydawnicza IMPULS, 2007. - 170 s.

4. Kolman R. Kwalitologia. Wiedza o różnych dziedzinach jakości / R. Kolman. - Warszawa : Wydawnictwo Placet, 2009. - 485 s.

5. Tatarkiewicz W. Historia filozofii [Електронний реcypc]. - http://iklasyk.eu/wp-content/uploads/2015/03/W.Tatarkiewicz-Historia-Filozofii-Tom-I.pdf.

6. Derbis R. Poczucie jakości życia a swoboda działania i odpowiedzialność / R. Derbis, A. Bańka. - Poznan, 1998. - $156 \mathrm{~s}$

7. Sadowska-Snarska C. Elastyczne formy pracy jako instrument ułatwiający godzenie życia zawodowego z rodzinnym / C. Sadowska-Snarska. - Białzstok : Wydawnictwo Wyższej Szkoły Ekonomicznej, 2006.-127 s.

8. Kowalik S. Jakość życia psychicznego: w: R. Derbis (red.). Jakość rozwoju a jakość życia / S. Kowalik. Częstochowa : WSP, 2000. - S. 11-32.

9. Wachowiak A. Jak żyć?: wybrane problemy jakości życia / A. Wachowiak. - Zielona Górra : Wyższa Szkoła Pedagogiczna im. Tadeusza Kotarbińskiego, 2001. - 260 s.

10. Rapley M. Beyondhelp A Consumer's Guide to Psychology / M. Rapley, S. Hansen, A. McHoul. - United Kingdom, Manchester : PCCS Books, 2003. - 256 p.

11. Bańka A. Jakość życia w psychologicznych koncepcjach człowieka i pracy. [w] Psychologiczne i pedagogiczne wymiary jakości życia / A. Bańka, R. Derbis (red). - Poznań : UAM, 1994. - S.19-40.

12. Seligman Martin E. P. Positive psychology progress: empirical validation of interventions / Martin E. P. Seligman,

\section{References}

1. Baumann, K. (2006). Jakość życia w okresie późnej dorosłości - dyskurs teoretyczny. Gerontologia Polska, 14 (4), 165-171.

2. Pszczołowski, T. (1978). Mała encyklopedia prakseologii i teorii organizacji. Wrocław, 346.

3. Daszykowska, J. (2007). Jakość życia w perspektywie pedagogicznej. Kraków: Oficyna Wydawnicza IMPULS, 170.

4. Kolman, R. (2009). Kwalitologia. Wiedza o różnych dziedzinach jakości. Warszawa: Wydawnictwo Placet, 485.

5. Tatarkiewicz, W. (2015). Historia filozofii. http://iklasyk. eu/wp-content/uploads/2015/03/W.-Tatarkiewicz-HistoriaFilozofii-Tom-I.pdf.

6. Derbis, R., \& Bańka, A. (1998). Poczucie jakości życia a swoboda działania i odpowiedzialność. Poznan, 156.

7. Sadowska-Snarska, C. (2006) Elastyczne formy pracy jako instrument ułatwiający godzenie życia zawodowego
Tracy A. Steen, Nansook Park, Christopher Peterson. American psychologist. - 2005/7. - T. 60, No. 5. - P. 874884.

13. Czapiński J. Diagnoza Społeczna 2009. Warunki i jakość życia Polaków.Raport / J. Czapiński, T. Panek. Warszawa, 2009. - 387 s.

14. Kubacka-Jasiecka D. Człowiek wobec zmiany. Rozważania psychologiczne wyd.1 / D. Kubacka-Jasiecka - Kraków : Wydawnictwo uniwersytetu Jagiellońskigo, 2002. - $168 \mathrm{~s}$

15. Nowosad I. Jakość życia i jakość szkoły. Wprowadzenie w zagadnienia jakości i efektywności pracy szkoły / I. Nowosad, I. Mortag, J. Ondráková. - Zielona Góra : Oficyna Wydawnicza UZ, 2010. - 381 s.

16. Wrona-Polańska H. Zdrowie i jego psychobiologiczne mechanizmy : Zdrowie, stres, choroba w wymiarze psychologicznym / pod red. nauk. Heleny Wrony-Polańskiej. Kraków : Oficyna Wydawnicza "Impuls”, 2008. - S. 17-36.

17. Juczyński Z. Szlachetne zdrowie, niech każdy się dowie / Z. Juczyński // Wychowanie Fizyczne i Zdrowotne. 1999. - No.3. - S. 95-97.

18. Sęk H. Psychologia zdrowia / H. Sęk, I. HeszenNiejodek. - Warszawa : Wydawnictwo Naukowe PWN, 1997. - $371 \mathrm{~s}$.

19. Wołowicka L. Przegląd badań nad jakością życia chorych po intensywnej terapii dorosłych. W: Wołowicka L. (red.). Jakość życia w naukach medycznych / L. Wołowicka. Poznań : Wyd. Akademii Medycznej, 2001. - 193 s.

20. Wiatrowska A. Jakość życia w zaburzeniach odżywiania/ A. Wiatrowska. - Lublin : Wydawnictwo UMCS, 2009. 174 s.

21. Kowalik S. W poszukiwaniu nowego wymiaru jakości życia związanego ze stanem zdrowia. [w:] Jakość życia w naukach medycznych. Wołowicka L (red) / S. Kowalik, A. Ratajska, A. Szmaus. - Poznań, 2002. - S. 17-29.

z rodzinnym. Białzstok: Wydawnictwo Wyższej Szkoły Ekonomicznej.

8. Kowalik, S. (2000). Jakość życia psychicznego: w: R. Derbis (red.). Jakość rozwoju a jakość życia. Częstochowa: WSP.

9. Wachowiak, A. (2001). Jak żyć?: wybrane problemy jakości życia. Zielona Górra: Wyższa Szkoła Pedagogiczna im. Tadeusza Kotarbińskiego.

10. Rapley, M., Hansen, S., \& McHoul, A. Beyondhelp (2003). A Consumer's Guide to Psychology. United Kingdom, Manchester : PCCS Books.

11. Bańka, A. (1994). Jakość życia w psychologicznych koncepcjach człowieka i pracy. [w] Psychologiczne i pedagogiczne wymiary jakości życia. Poznań: UAM, 19-40.

12. Seligman, P., Martin, Steen, A., Tracy, Park, Nansook, \& Peterson, Christopher (2007). Positive psychology progress: empirical validation of interventions. American Psychologist, 60 (5), 874-884. 
13. Czapiński, J., \& Panek, T. (Ed.) (2009). Diagnoza Społeczna 2009. Warunki i jakość życia Polaków. Raport. Warszawa.

14. Kubacka-Jasiecka, D. (2002). Człowiek wobec zmiany. Rozważania psychologiczne wyd.1 Kraków: Wydawnictwo uniwersytetu Jagiellońskigo, 168.

15. Nowosad, I., Mortag, I., \& Ondráková, J. (2010). Jakość życia i jakość szkoły. Wprowadzenie w zagadnienia jakości i efektywności pracy szkoły. Zielona Góra: Oficyna Wydawnicza UZ, 381.

16. Wrona-Polańska, H. (2008). Zdrowie i jego psychobiologiczne mechanizmy: Zdrowie, stres, choroba w wymiarze psychologicznym. Kraków: Oficyna Wydawnicza "Impuls”.

Електронна адреса для листування: kishylamj@tdmu.edu.ua
17. Juczyński, Z. (1999). Szlachetne zdrowie, niech każdy się dowie. Wychowanie Fizyczne i Zdrowotne, 3, 95-97.

18. Sęk, H., \& Heszen-Niejodek, I. (Ed.) (1997). Psychologia zdrowia. Warszawa: Wydawnictwo Naukowe PWN.

19. Wołowicka, L. (2001). Przegląd badań nad jakościq życia chorych po intensywnej terapii dorosłych. W: Wołowicka L. (red.). Jakość życia w naukach medycznych, Poznań: Wyd. Akademii Medycznej.

20. Wiatrowska, A. (2009). Jakość życia w zaburzeniach odżywiania. Lublin: Wydawnictwo UMCS.

21. Kowalik, S., Ratajska, A., \& Szmaus, A. (2002). W poszukiwaniu nowego wymiaru jakości życia zwiqzanego ze stanem zdrowia. [w:] Jakość życia w naukach medycznych. Wołowicka L. (red). Poznań. 